\title{
Neurosteroid Hormones Modulate the Differentiation of Adult Human Multipotent Mesenchymal Stromal Cells
}

\author{
B. I. Tiftikcioglu' ${ }^{1}$ C. M. Rice ${ }^{2}$, R. Karabudak ${ }^{3}$ and N. J. Scolding ${ }^{2 *}$ \\ ${ }^{1}$ Hacettepe University School of Medicine, Department of Neurology, Ankara, Turkey \\ ${ }^{2}$ University of Bristol, Institute of Clinical Neurosciences, Frenchay Hospital, Bristol, UK \\ ${ }^{3}$ Hacettepe University School of Medicine, Department of Neurology, Neuroimmunology Unit, Ankara, Turkey
}

\begin{abstract}
Objective: To examine the effect of neurosteroids on human multipotent mesenchymal stromal cell (hMSCs) neuroglial differentiation.

Materials and methods: Human MSCs were isolated and expanded in vitro. The expression of neurosteroid receptors by hMSCs was examined using immunocytochemistry and the effect of neurosteroids on the proliferation and differentiation of hMSCs was investigated using immunocytochemistry and the 3-(4,5-dimethylthiazol-2-yl)-2,5diphenyl tetrazolium bromide (MTT) survival assay.

Results: Human MSCs express receptors for neurosteroids. Nestin expression is decreased by neurosteroids Neurosteroids also exert differential effects depending on the gender of the hMSC donor; dihydrotestosterone (DHT) was responsible for maximal A2B5 expression in hMSCs from male donors whereas 17- $\beta$ estradiol (E2) exerted the greatest effect on differentiation of 'female' hMSCs. Maximal effects of E2 and DHT were observed at a concentration of $100 \mathrm{nM}$, progesterone (PROG) at $250 \mathrm{nM}$. The neurosteroid-induced increase in oligodendroglial differentiation was abrogated by specific receptor antagonists for E2, PROG and DHT. High concentrations of neurosteroids were toxic for hMSCs, irrespective of gender.
\end{abstract}

Conclusions: These results suggest a significant role for neurosteroid hormones in the differentiation of hMSCs and may have important implications for the development of MSC transplantation therapy for multiple sclerosis and in autoimmune diseases.

Keywords: Neurosteroids; Human multipotent mesenchymal stromal cells; Oligodendrocytes; Cell differentiation; Multiple Sclerosis

\section{Introduction}

Neurosteroids are those steroid hormones which, independent of their origin, are capable of modifying neural activities [1]. They can act through classical/genomic or rapid/non-genomic pathways within the CNS. Since the discovery of de novo synthesis of dehydroepiandrosterone sulpate (DHEAS) from cholesterol in the brain tissue by Baulieu in 1981 (so-called neurosteroid synthesis) [2], the direct synthesis of the majority of the steroid hormones such as pregnenalone, progesterone and sex steroids, estradiol, testosterone and dihydrotestosterone and the presence of key enzymes for steroid synthesis have been demonstrated in CNS tissue [3,4]. Neurosteroids are produced in particular in myelinating glial cells, though also in astrocytes and in neurons [5]. Within the CNS, neurosteroids appear to exert a variety of effects [6,7], not least on proliferation and differentiation of cells of neural lineage.

More specifically, a number of authors have reported the presence of neurosteroid hormone receptors on oligodendrocytes (OLG). These are the cells responsible for synthesising and maintaining myelin in the CNS, and they form, together with myelin, the principal target for immune damage in Multiple Sclerosis (MS), the commonest acquired disease causing neurological disability in young adults. MS has a pronounced gender bias (more than twice as common in females), and a number of sex steroid changes have been documented in this disease. Significant neurosteroid effects on oligodendrocytes [8-11], on oligodendrocyte progenitors [12], and on pre-progenitors [13,14], have been reported. Neurosteroids also exert effects on neural stem cells [15].
Adult bone marrow-derived multipotent mesenchymal stromal cells (MSCs) are multipotent cells that can differentiate into various cell phenotypes including hepatic cells, skeletal and cardiac myocytes, as well as bone, cartilage and fat cells [16-19]. Bone marrow -derived cells have been shown to express neuroectodermal markers [20,21], and can differentiate into cells with both the phenotype and function of myelinating glia [22,23], findings which have prompted much interest in the potential development of new therapeutic strategies in neurodegenerative diseases [24].

We hypothesized that neurosteroid hormones were likely to exert significant effects on the biology and behaviour of MSCs. Here we investigate this possibility by studying the expression of neurosteroid receptors on human MSCs (hMSCs), and the effects of the neurosteroid hormones $17 \beta$-estradiol (E2), progesterone (PROG) and dihydrotestosterone (DHT) on the differentiation of hMSCs in vitro, studying in particular the expression of nestin, which is seen

${ }^{*}$ Corresponding author: Professor Neil J. Scolding PhD FRCP, Burden Professor of Clinical Neurosciences, University of Bristol Institute of Clinical Neurosciences, Department of Neurology, Frenchay Hospital, Bristol, BS16 1LE, UK, Tel: +44 (0) 117970 1212; Fax: +44(0) 117975 3824; E-mail: Diane.Millard@north-bristol.swest.nhs.uk

Received December 04, 2011; Accepted January 04, 2011; Published January 06, 2012

Citation: Tiftikcioglu BI, Rice CM, Karabudak R, Scolding NJ (2012) Neurosteroid Hormones Modulate the Differentiation of Adult Human Multipotent Mesenchymal Stromal Cells. J Stem Cell Res Ther S4:003. doi:10.4172/2157-7633.S4-003

Copyright: (c) 2012 Tiftikcioglu $\mathrm{BI}$, et al. This is an open-access article distributed under the terms of the Creative Commons Attribution License, which permits unrestricted use, distribution, and reproduction in any medium, provided the original author and source are credited. 
in neural stem cells but not their more differentiated progeny, and of A2B5, expressed by oligodendrocyte progenitors in vitro but not by uncommitted neural stem cells.

\section{Materials and Methods}

\section{Isolation and culture of hMSCs}

Local ethics committee approval for the collection of hMSCs from patients undergoing total hip replacement was obtained. Patients were formally consented for marrow donation. Mononuclear cells were isolated using a density gradient (Lymphoprep, Axis-Shield PoC AS) and incubated with $0.15 \mathrm{M}$ ammonium chloride, $0.01 \mathrm{M}$ potassium bicarbonate and $0.15 \mathrm{mM}$ EDTA in $\mathrm{ddH} 2 \mathrm{O}$ at $4^{\circ} \mathrm{C}$ for 10 minutes to lyse red blood cells. MSCs were plated at a density of $4 \times 10^{5} / \mathrm{cm}^{2}$ and incubated with standard hMSC medium [Dulbecco's modified eagle's medium (D5523, Sigma) supplemented with $10 \%$ foetal bovine serum (FBS, StemCell Technologies Inc., Canada, 06471)]. Cultures were incubated in a humidified, $5 \% \mathrm{CO}_{2}$ atmosphere at $37^{\circ} \mathrm{C}$ and the medium exchanged every 5-7 days. Upon reaching a minimum of $80 \%$ confluence, adherent cells were passaged with trypsin (TrypsinEDTA, BE17-161E, Cambrex) and replated at $0.5 \times 10^{6}$ cells per T75 flask. Cells beyond second passage conform to the defining criteria for MSCs as published by the International Society for Cellular Therapy position statement [25] (results not illustrated) and were plated at $1 \times 10^{3} / \mathrm{cm}^{2}$ onto PLL-coated (P5899, Sigma) glass coverslips in 4-well chamber slides containing standard hMSC medium. The medium was exchanged at 24hrs and supplemented with E2 (E2758, Sigma), PROG (P7556, Sigma) or DHT (A8380, Sigma). DHT was used because it is not a substrate for aromatase conversion to estrogen. Stock solutions in ethanol of E2, PROG and DHT (1000nM) were diluted into hMSC cultures at $0.01 \mathrm{nM}, 0.1 \mathrm{nM}, 1 \mathrm{nM}, 5 \mathrm{nM}, 10 \mathrm{nM}, 50 \mathrm{nM}, 100 \mathrm{nM}, 250 \mathrm{nM}$, $500 \mathrm{nM}$ and $1000 \mathrm{nM}$ concentrations. The final concentration of ethanol in culture medium was $<0.03 \%$. The optimal concentration of neurosteroid was determined using a single, male marrow. The effects of this optimal hormone concentration were further examined using a female and additional male marrow.

\section{Detection of steroid hormone receptors on hMSCs}

Adult hMSCs from both male and female donors were plated in standard hMSC culture medium and fixed with $4 \%$ paraformaldehyde (Alrich 15,812-7) in potassium buffered saline (PBS) (Sigma P4417) for 5 minutes. Cells were permeabilized with ice-cold methanol for 10 minutes at $-20^{\circ} \mathrm{C}$. Prior to application of primary antibody [antiestrogen receptor- $\alpha$ (anti-ER $\alpha$ ) (mc-20, Santa Cruz Biotechnology, Inc., CA, $1 \mu \mathrm{g} / \mathrm{ml}$ ), anti-estrogen receptor- (anti-ER $\beta$ ) (AB1410, Chemicon, UK, 1:300), anti-progesterone receptor (anti-PR) (MAB462, Chemicon, UK, 1:1000), anti-androgen receptor (anti-AR) (PG-21, Chemicon, UK, 1:100)] cells were incubated with PBS supplemented with 5\% normal goat serum (NGS; S-1000, Vector Laboratories Inc., CA) for 30 minutes at room temperature. Cells were incubated with appropriate secondary antibodies (AF488 goat anti-rabbit IgG or AF488 goat anti-mouse $\operatorname{IgG}_{22}$, Molecular Probes, Invitrogen, UK, $1: 1000)$. In all cases, isotype control staining experiments were carried out and little discernible non-specific or background staining was observed (results not illustrated). The nuclei were counterstained with Hoescht. Coverslips were mounted onto glass slides with Vectashield (H1000, Vector Lab., CA).

\section{Effects of neurosteroids on in vitro oligodendroglial lineage} differentiation of hMSCs as detected by immunocytochemistry

Adult hMSCs from a male donor were maintained for 7 days in media containing various concentrations of E2, PROG or DHT and stained for early oligodendroglial cell markers. Cells were doublestained for A2B5 (MAB1416, R\&D Systems, UK, $2 \mu \mathrm{g} / \mathrm{ml}$ ) and nestin (MAB5326, Chemicon, UK, 1:400). A2B5 staining was performed live; cells were first incubated in a humidified chamber for 30 minutes at $37^{\circ} \mathrm{C}$ with $5 \% \mathrm{NGS}$ and subsequently with anti-A2B5 antibody. Cells were then processed for intracellular staining (see above). We concentrated on the expression of A2B5, an accepted marker oligodendroglial lineage and differentiation, at least in cell culture studies [26], and a powerful indicator of oligodendrocyte progenitor differentiation potential, as others have used this marker in sex steroidoligodendrocyte lineage studies [27].

\section{Co-expression of steroid hormone receptors and A2B5}

Adult hMSCs were cultured on PLL-coated coverslips with the optimal concentration of E2, PROG and DHT. On day 7, coverslips were double-stained with antibodies against the relevant receptor and A2B5.

\section{Specificity of steroid hormone effect}

To investigate whether the observed effects of steroid hormones were mediated through the relevant receptors ICI $182,780(1000 \mathrm{nM}$, Tocris, UK), mifepristone (10,000nM, M8046, Sigma, UK) and flutamide (100nM, F9397, Sigma, UK) were used as selective receptor antagonists for E2, PROG and DHT respectively [28-30].

\section{Expression of other oligodendrocyte precursor cell markers}

Adult hMSCs cultured in standard medium supplemented with 100nM E2, 250nM PROG or 100nM DHT were stained with antiPDGFaR and anti-NG2 antibodies at 7 days.

\section{MTT proliferation assay}

Cell survival was measured by the 3-(4,5-dimethylthiazol-2-yl)2,5-diphenyl tetrazolium bromide (MTT) survival assay (M5655, Sigma, UK). Viable cells with active mitochondria reduce MTT to form a visible dark blue formazan reaction product. Briefly, hMSCs were incubated with $1 \mathrm{mg} / \mathrm{ml}$ of MTT in standard culture medium for 1 hour at $37^{\circ} \mathrm{C}$. The supernatant was aspirated and the formazan product dissolved in isopropanol. A Multiskan Ascent spectrophotometer was used to measure the specific absorbance at $540 \mathrm{~nm}$.

\section{Cell counts}

Stained cells were visualized and manually counted in predesignated areas with Leica FW4000-TZ fluorescent microscope and photographed with Leica DFC350-FX digital camera with the assistance of Leica FW4000 fluorescent imaging software. The number of total cells was evaluated by counting Hoescht-positive nuclei.

\section{Statistics}

SPSS statistical package (SPSS 13.0) was used for statistical analysis one-way analysis of variance (ANOVA) and post-hoc multiple comparisons (Dunnett's multiple comparison test). Results from the various steroid hormone concentrations were compared with those from cells treated with standard (hormone-deficient) medium. Values of $\mathrm{p}<0.05$ were considered significant. 
Citation: Tiftikcioglu BI, Rice CM, Karabudak R, Scolding NJ (2012) Neurosteroid Hormones Modulate the Differentiation of Adult Human Multipotent Mesenchymal Stromal Cells. J Stem Cell Res Ther S4:003. doi:10.4172/2157-7633.S4-003

\section{Results}

\section{Adult hMSCs express neurosteroid hormone receptors}

Adult hMSCs both from male and female donors were stained for the expression of neurosteroid hormone receptors. Expression was uniformly high in all hMSC cultures examined and no significant effect of gender was observed. Expression of ERa was seen preferentially in the cell nucleus, but cytoplasmic staining was also observed (Figure 1a). ER $\beta$ expression appeared to be localized to the cytoplasm mainly (also as expected; Figure 1b). PR and AR expression was seen predominantly in the cell nucleus (Figure 1c and 1d). Addition of steroid hormone to the culture medium did not discernibly change the visible intensity or distribution of steroid hormone receptor immunostaining (Figure 1e-h).

Neurosteroid hormones enhance the oligodendroglial progenitor differentiation of hMSCs and inhibit cell proliferation

Treatment with various concentrations of neurosteroid hormones revealed significant effects on the differentiation of male donor-derived hMSCs. All three neurosteroids reduced the expression of the neural stem cell lineage marker nestin. This effect was seen for DHT over a concentration range of $1-250 \mathrm{nM}(\mathrm{p}<0.01)$, for $\mathrm{E} 2$ at greater than $0.1 \mathrm{nM}$ and less than $1000 \mathrm{nM}(\mathrm{p}<0.05)$ and for PROG at all concentrations

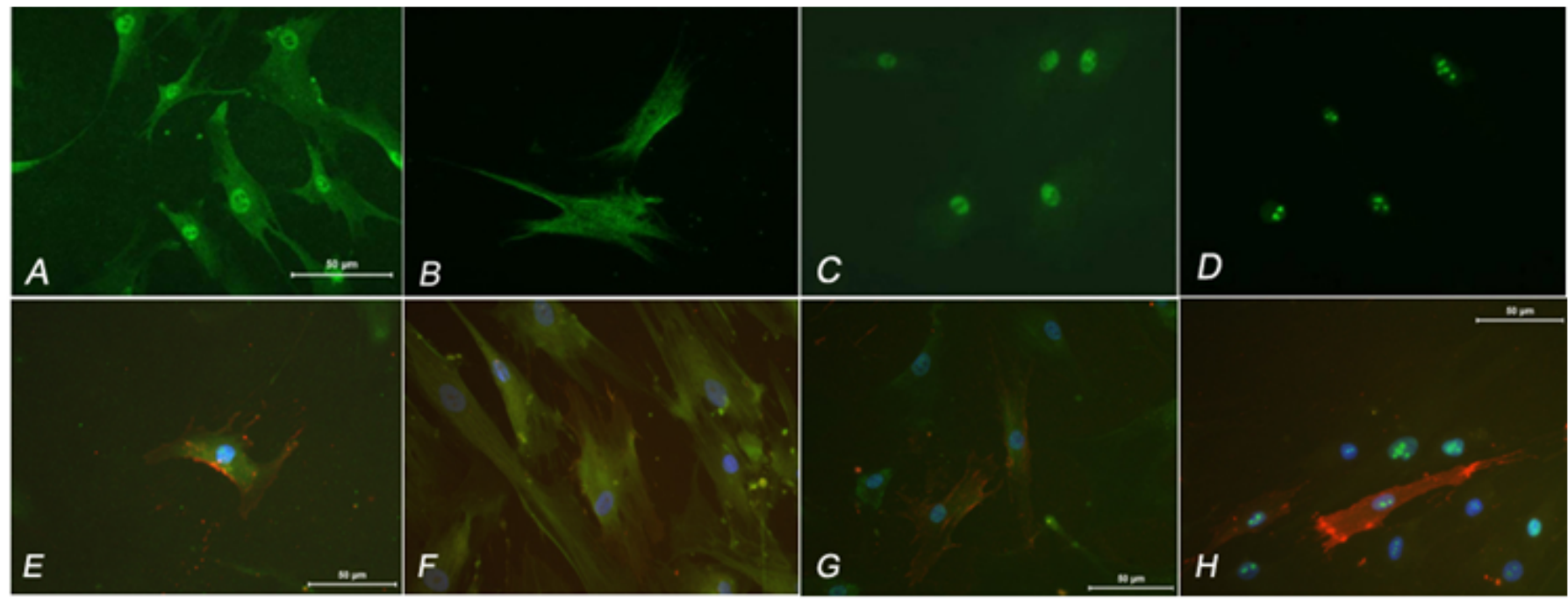

Figure 1: Adult hMSCs express neurosteroid hormone receptors. A. Oestrogen receptor (ER)a, B. Oestrogen receptor (ER) $\beta$, C. Progesterone Receptor (PR), D. Androgen receptor (AR). E-H: Co-expression of neurosteroid hormone receptors (green) and A2B5 (red) after hormone exposure: (E) ERa after E2 exposure; (F) ERB after E2 exposure; (G) PR after PROG exposure; (H) AR after DHT exposure.

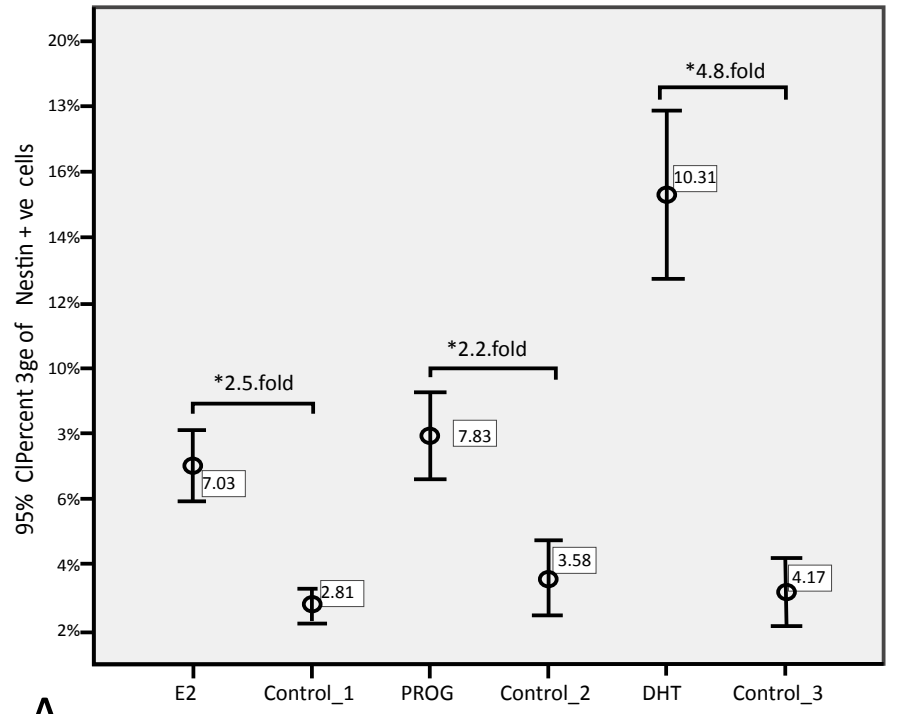

Neuroactive Steroid Hormone Treated vs. Standard Cultures

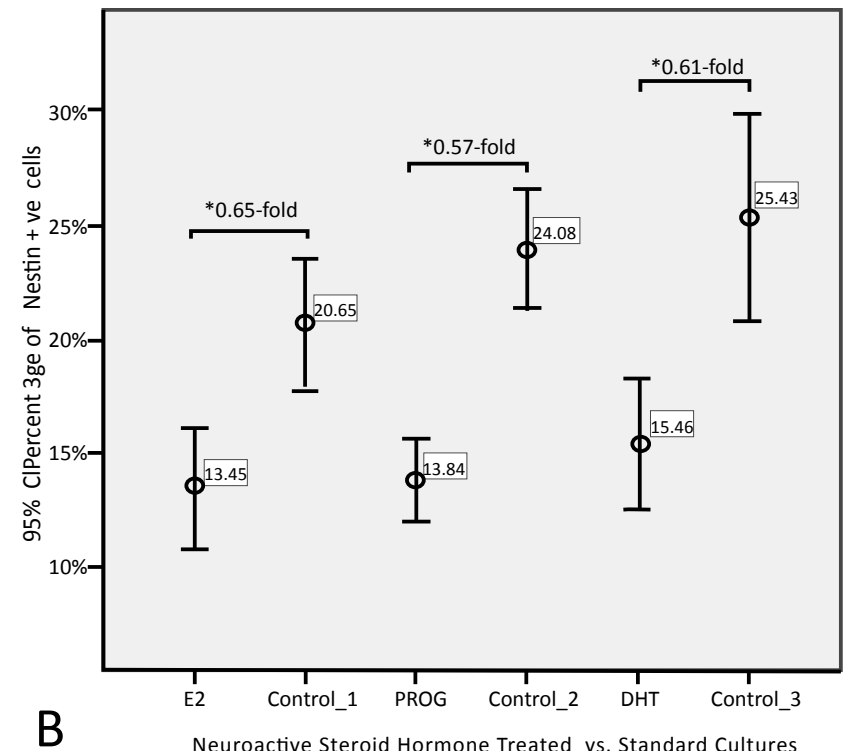

Neuroactive Steroid Hormone Treated vs. Standard Cultures

Figure 2: The effect of neurosteroid hormones on the oligodendroglial differentiation of adult hMSCs. At the most effective concentrations (i.e. 100nM for E2 and DHT and 250nM for PROG; * $\mathrm{p}<0.01$ ), ratios for the increased expression of A2B5 +ve cells $(A)$ and the decreased expression of nestin +ve cells (B) were calculated in comparison with hormone-deficient (standard) cultures. 
Citation: Tiftikcioglu BI, Rice CM, Karabudak R, Scolding NJ (2012) Neurosteroid Hormones Modulate the Differentiation of Adult Human Multipotent Mesenchymal Stromal Cells. J Stem Cell Res Ther S4:003. doi:10.4172/2157-7633.S4-003

Page 4 of 7

examined $(\mathrm{p}<0.01)$. Addition of ethanol alone $(0.03 \%)$ to MSC cultures did not alter the expression of nestin.

DHT, E2 and PROG enhanced the expression of A2B5, a marker of oligodendrocyte progenitors, in all applied doses (Figure 1e-h, Figure 2a), although this effect was not statistically significant at very low concentrations $(0.01 \mathrm{nM})$ of E2 and PROG, or at high concentrations of PROG $(1000 \mathrm{nM})$. The most effective concentrations were $100 \mathrm{nM}$, $250 \mathrm{nM}$ and $100 \mathrm{nM}$ for E2, PROG and DHT, respectively $(\mathrm{p}<0.01)$. Addition of ethanol alone did not change the expression of A2B5. At these most active concentrations, DHT increased A2B5-positive cell numbers 4.8 -fold, whereas, E2 and PROG increased the relative expression of A2B 5 by 2.5 - and 2.2-fold respectively (Figure 2a). Nestin expression, by contrast, was decreased by $0.65-, 0.57$ - and 0.61 -fold with treatment with E2, PROG and DHT respectively (Figure $2 \mathrm{~b}$ ).

The effects of the optimal hormone concentration were further examined using additional male and female marrows. The results for the male marrow replicated those found in the original study; nestin expression was reduced in steroid-treated cultures and DHT, E2 and PROG increased A2B5 expression by 5.3-, 3.3-, and 4.1-fold respectively. Nestin expression was decreased in the female marrow by culture with neurosteroids, but only E2 administration increased A2B5 expression significantly (2.4-fold).

The neurosteroid-induced decrease in nestin expression, together with the increase in the proportion of hMSCs expressing A2B5, is consistent with differentiation. Although total cell number decreased only with very high concentrations of neurosteroids, we cannot speculate on whether differential expansion and apoptosis of subpopulations of cells has occurred on the basis of the experiments performed to date.

\section{Co-administration of neurosteroid receptor antagonists inhibits the effect on differentiation}

Administration of specific receptor antagonists, ICI 182,780, mifepristone and flutamide, together with E2, PROG and DHT, abolished the previously observed changes in nestin and A2B5 expression, indicating that the $\mathrm{ER} \alpha, \mathrm{ER} \beta, \mathrm{PR}$ and ARs have functional roles in the oligodendroglial differentiation of adult hMSCs. On day 7 , the proportion of cells double-labeled with antibodies against nestin and A2B5 were not significantly different compared to cultures treated with standard, hormone-deficient medium (Figure 3).

\section{Expression of other oligodendrocyte precursor cell markers}

On day 7, hMSCs cultured in standard medium supplemented with 100nM E2, 250nM PROG or 100nM DHT were stained for the presence of the alternative oligodendrocyte progenitor markers PDGFaR and NG2. Hormone-treated cultures had increased numbers of cells expressing the PDGFaR as compared to standard cultures, although this did not reach statistical significance. Unexpectedly, all cells were positive for NG2; no difference was observed between hormone treated and standard cultures.

\section{Neurosteroid hormones exert lethal effects on mesenchymal stem cells at higher concentrations}

It became evident during these studies that higher concentrations of all three neurosteroid hormones resulted in a decrease in cell numbers in adult human MSCs in vitro. MTT assays revealed that concentrations of PROG and DHT of $1000 \mathrm{nM}$ or greater, exhibited a significant toxic effect on hMSCs, resulting in cell death, which was comparable to that of paraformaldehyde administration. Co-culture with high concentrations of E2 showed a trend towards decreased cell viability but this was not significant (Figure 4).

\section{Discussion}

Bone marrow (BM) stroma contains multipotent progenitors that appear to be able to give rise to mature cells of mesenchymal and non-mesenchymal lineages, including neurons and glia [31-33] BM-derived cells, presumably immature precursors or stem cells, can enter the brain and differentiate into neural cells in both mice $[34,35]$ and humans [36]. Intra-lesional or intravenous delivery of adult BMderived cells enhances remyelination in the rat spinal cord [37-39]. Such cells are therefore very promising candidates for transplantation
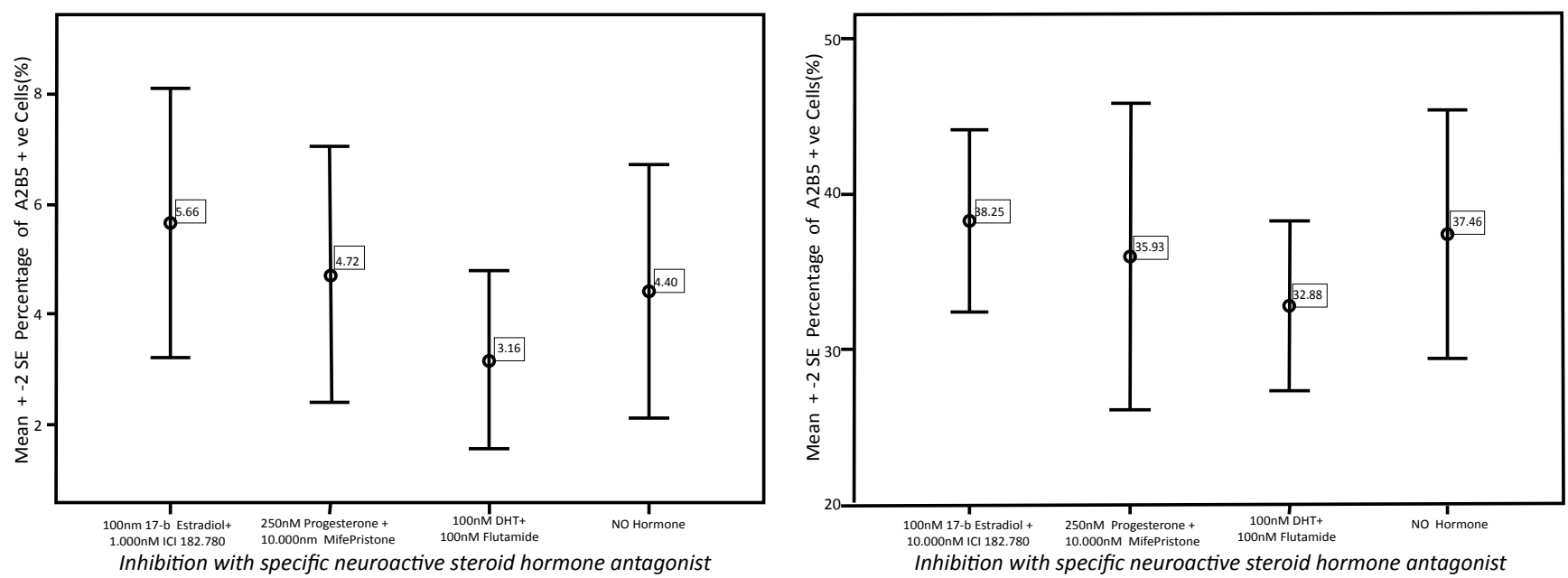

Figure 3: Specific neurosteroid hormone receptor antagonists abrogate neurosteroid effects on the expression of A2B5 (A) and of nestin (B) by adult hMSCs; results were not different from untreated cultures $(p>0.05)$. 


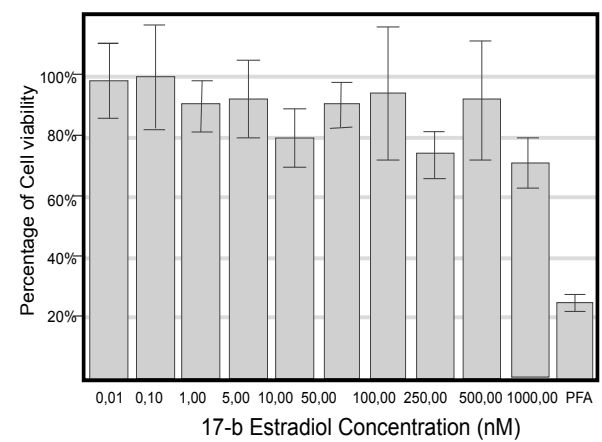

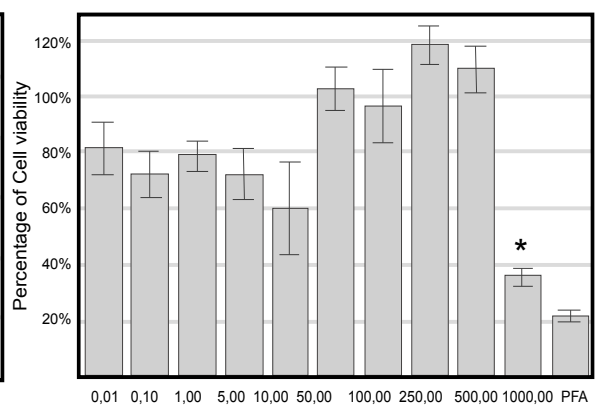

Progesterone Concentration (nM)

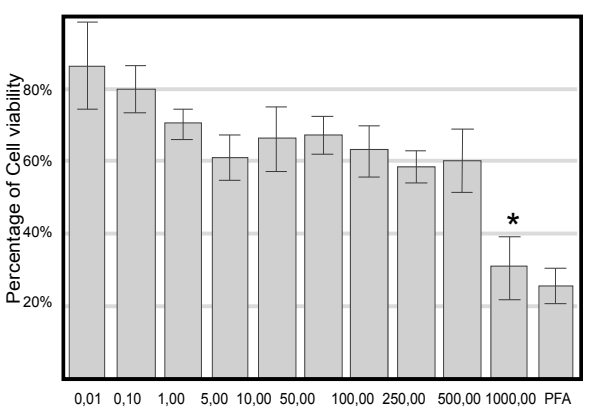

DHT Concentration (nM)

Figure 4: High concentrations of neurosteroids are toxic to adult hMSCs. This was most marked when hMSCs were incubated with high concentrations (1000nM) of PROG and DHT (cell numbers were compared to PFA administration, $\mathrm{p}>0.05$ ) but there was also a negative trend with increasing concentrations of E2. Error bars show $95.0 \% \mathrm{Cl}$ of mean.

therapy; they are relatively accessible, autologous, and not complicated by the ethical issues surrounding the use of embryonic stem cells. BM-derived cells have been used for decades in the treatment of hematological malignancy. The extensive safety data collected over this period has facilitated the rapid transition from laboratory to clinic, and early phase clinical trials employing bone marrow-derived cells in the treatment of neurological disease have been completed [40,41].

In MS, both the incidence and prevalence in women are over twice that in men [42]. Other autoimmune diseases also show a female predominance, including rheumatoid arthritis, psoriasis and thyroiditis. The phenotype of MS in male patients tends to be more severe; males are more likely to have primary progressive MS, in which disability is relentlessly progressive.

A disruption of the hypothalamo-pituitary-gonadal axis and diminished production of sex hormones has been reported in both MS and the animal model experimental allergic encephalomyelitis (EAE). In addition, MS patients are known to have lower serum concentrations of oestrone sulphate than healthy controls, although this does not correlate with disease severity [43]. Male mice with EAE, and male MS patients, have low serum testosterone levels [44]. Oestrogens modulate the activity of MS during pregnancy $[45,46]$ in association with an immune shift from Th-1 to T helper type-2 (Th-2) [47]. Treatment with the predominant estrogen in pregnancy, oestriol, temporarily decreases the number of enhancing lesions on brain MRI of relapsing remitting MS patients [48]. This effect has also been observed in rodent EAE where pregnancy suppresses both the disease onset [49] and relapses [50]. Gonadectomy increases the severity of EAE irrespective of gender $[51,52]$, whereas treatment with oestrogens or androgens suppressed the disease [53-56].

Estrogen may mediate its effects by binding to the estrogen receptors ER $\alpha$ and ER $\beta$, and a newly recognized ER-X. Zhang et al. reported the presence of both ER $\alpha$ and ER $\beta$ in an OLG cell line and in enriched OLG cultures [57], and showed that ERa receptors are located in the OLG nucleus, whereas ER $\beta$ receptors are cytoplasmic. Adding oestriol to glial cultures enhanced differentiation of OLGs [58]. Estrogen significantly decreases the cytotoxicity of the peroxynitrite generator 3-(4-morpholinyl)-sydnonimine (SIN-1) in both immature and mature OLGs in a dose-dependent manner and is neuroprotective for OLGs [59]. Estrogen increases CNS myelination in the rat [60].

PROG, synthesized by Schwann cells, promotes the formation of new PNS myelin sheaths $[61,62]$. PROG also stimulates myelination by OLGs in the CNS. When added to organotypic slice cultures of rat and mouse cerebellum, PROG accelerated myelin formation, irrespective of gender, via the intracellular receptor (PR); its effect was blocked by the PR antagonist mifepristone (RU486), and PROG had no effect on myelination in cerebellar slice cultures from PR knockout mice [63]. In the CNS of old male rats, PROG promoted remyelination of axons by OLGs after toxic demyelination [64]. PROG is synthesized only in the early stages of oligodendrocyte precursor cell (OPC) differentiation, but is highly metabolized by OLGs. In addition, the neurosteroid, $3 a$, $5 \beta$-THPROG, is principally formed by OPCs [65].

The effects of androgens in the nervous system are less well characterized. Testosterone may be neuroprotective, either directly or indirectly via its aromatization to estradiol [66]. The role of androgens, specifically testosterone, in the pathophysiology of demyelinating diseases of CNS is rather controversial. While women are more susceptible to MS, men are more likely to have progressive and severe disease [67]. Although several reports declare that testosterone is protective in EAE models [68], Caruso et al. demonstrated that testosterone makes OLGs more vulnerable to excitotoxic death; the toxic effects of kainite or AMPA and cyclothiazide were amplified after the administration of testosterone into short-term pure cultures of OLGs (4 days in vitro)[69].

In summary therefore, studies of MS epidemiology and myelination biology indicate that female sex steroids are associated with an ameliorating effect on the course of MS, and exert a positive influence on the myelinating and remyelinating activity of CNS glia. A number of observers have, not surprisingly, linked these observations [70,71]. Our findings enhance our understanding of the role of neurosteroids in cell differentiation and, more specifically, represent the first evidence that adult stem cells are clearly neurosteroid responsive, neurosteroids decreasing proliferation and nestin expression, and encouraging the oligodendroglial differentiation of hMSCs. These observations raise the possibility that in the future, as we come to a broader and deeper understanding of the role of these molecules in stem cell development, currently available neurosteroids may be used therapeutically to enhance spontaneous (or extraneous) stem cell repair processes. Conversely, the toxic effect we found at higher doses serves as a potentially valuable caution that inappropriate dosing might not 
Citation: Tiftikcioglu BI, Rice CM, Karabudak R, Scolding NJ (2012) Neurosteroid Hormones Modulate the Differentiation of Adult Human Multipotent Mesenchymal Stromal Cells. J Stem Cell Res Ther S4:003. doi:10.4172/2157-7633.S4-003

simply have neutral effects, but may be positively detrimental to repair and regeneration in the central nervous system.

\section{Acknowledgements}

B.I.T. is supported by E.N.S. Fellowship. C.M.R is supported by a Patrick Berthoud Clinical Research Fellowship. The Burden Chair of Clinical Neurosciences (N.J.S) is supported by The Burden Trust. The authors have no conflict of interest to declare.

\section{References}

1. Reddy DS (2010) Neurosteroids: endogenous role in the human brain and therapeutic potentials. Prog Brain Res 186: 113-137

2. Baulieu EE (1998) Neurosteroids: a novel function of the brain. Psychoneuroendocrinology 23: 963-987.

3. Hojo Y, Hattori TA, Enami T, Furukawa A, Suzuki K, et al. (2004) Adult male rat hippocampus synthesizes estradiol from pregnenolone by cytochromes P45017alpha and P450 aromatase localized in neurons. Proc Natl Acad Sci USA 101: 865-870

4. Murakami G, Tanabe N, Ishii HT, Ogiue-Ikeda M, Tsurugizawa T, et al. (2006) Role of cytochrome p450 in synaptocrinology: endogenous estrogen synthesis in the brain hippocampus. Drug Metab Rev 38: 353-369.

5. Baulieu EE (1998) Neurosteroids: a novel function of the brain. Psychoneuroendocrinology 23: 963-987.

6. Mellon SH, Griffin LD (2002) Neurosteroids: biochemistry and clinica significance. Trends Endocrinol Metab 13: 35-43.

7. Stoffel-Wagner B (2003) Neurosteroid biosynthesis in the human brain and its clinical implications. Ann N Y Acad Sci 1007: 64-78.

8. Baulieu EE (1998) Neurosteroids: a novel function of the brain Psychoneuroendocrinology 23: 963-987.

9. Baulieu E, Schumacher M (2000) Progesterone as a neuroactive neurosteroid with special reference to the effect of progesterone on myelination. Steroids 65: 605-612.

10. Ghoumari AM, Ibanez C, El-Etr M, Leclerc P, Eychenne B, et al. (2003) Progesterone and its metabolites increase myelin basic protein expression in organotypic slice cultures of rat cerebellum. J Neurochem 86: 848-859.

11. Guzman CB, Deighton-Collins S, Martinez A, Kleerekoper M, Zhao C, et al (2005) Activity of estradiol and selective estrogen receptor modulators in the mouse N20.1 oligodendrocyte/astrocytes cell line. Neuro Endocrinol Lett 26 526-532.

12. Marin-Husstege $M$, Muggironi M, Raban D, Skoff RP, Casaccia-Bonnefil $P$ (2004) Oligodendrocyte progenitor proliferation and maturation is differentially regulated by male and female sex steroid hormones. Dev Neurosci 26: 245 254

13. Gago N, Akwa Y, Sananes N, Guennoun R, Baulieu EE, et al. (2001) Progesterone and the oligodendroglial lineage: stage-dependent biosynthesis and metabolism. Glia 36: 295-308.

14. Gago N, El-Etr M, Sananes N, Cadepond F, Samuel D, et al. (2004) 3alpha,5alpha-Tetrahydroprogesterone (allopregnanolone) and gammaaminobutyric acid: autocrine/paracrine interactions in the control of neonatal PSA-NCAM+ progenitor proliferation. J Neurosci Res 78: 770-783.

15. Suzuki M, Wright LS, Marwah P, Lardy HA, Svendsen CN (2004) Mitotic and neurogenic effects of dehydroepiandrosterone (DHEA) on human neural stem cell cultures derived from the fetal cortex. Proc Natl Acad Sci USA 101: 3202 3207.

16. Pittenger MF, Mackay AM, Beck SC, Jaiswal RK, Douglas R, et al. (1999) Multilineage potential of adult human mesenchymal stem cells. Science 284 143-147.

17. Lagasse E, Connors H, Al Dhalimy M, Reitsma M, Dohse M, et al. (2000) Purified hematopoietic stem cells can differentiate into hepatocytes in vivo. Nat Med 6: 1229-1234.

18. Ferrari G, Cusella-De Angelis G, Coletta M, Paolucci E, Stornaiuolo A, et al.
(1998) Muscle regeneration by bone marrow-derived myogenic progenitors Science 279: 1528-1530

19. Jackson KA, Majka SM, Wang H, Pocius J, Hartley CJ, et al. (2001) Regeneration of ischemic cardiac muscle and vascular endothelium by adult stem cells. J Clin Invest 107: 1395-1402.

20. Jiang Y, Jahagirdar BN, Reinhardt RL, Schwartz RE, Keene CD, et al. (2002) Pluripotency of mesenchymal stem cells derived from adult marrow. Nature 418: 41-49.

21. Sanchez-Ramos J, Song S, Cardozo-Pelaez F, Hazzi C, Stedeford T, et al. (2000) Adult bone marrow stromal cells differentiate into neural cells in vitro. Exp Neurol 164: 247-256

22. Kocsis JD, Akiyama Y, Radtke C (2004) Neural precursors as a cell source to repair the demyelinated spinal cord. J Neurotrauma 21: 441-449.

23. Suzuki H, Taguchi T, Tanaka H, Kataoka H, Li Z, et al. (2004) Neurospheres induced from bone marrow stromal cells are multipotent for differentiation into neuron, astrocyte, and oligodendrocyte phenotypes. Biochem. Biophys Res Commun 322: 918-922

24. Scolding N (2011) Adult stem cells and multiple sclerosis. Cell Prolif 44: 35-38.

25. Dominici M, Le BK, Mueller I, Slaper-Cortenbach I, Marini F, et al. (2006) Minimal criteria for defining multipotent mesenchymal stromal cells. The International Society for Cellular Therapy position statement. Cytotherapy 8 : 315-317.

26. Dietrich J, Noble M, Mayer-Proschel M (2002) Characterization of A2B5+ glial precursor cells from cryopreserved human fetal brain progenitor cells. Glia 40 65-77.

27. Palacios G, Muro A, Vela JM, Molina-Holgado E, Guitart X, et al. (2003) Immunohistochemical localization of the sigma1-receptor in oligodendrocytes in the rat central nervous system. Brain Res 961: 92-99.

28. Wakeling AE, Dukes M, Bowler J (1991) A potent specific pure antiestrogen with clinical potential. Cancer Res 51: 3867-3873.

29. Brogden RN, Goa KL, Faulds D (1993) Mifepristone. A review of its pharmacodynamic and pharmacokinetic properties and therapeutic potential. Drugs 45: 384-409.

30. Brogden RN, Chrisp P (1991) Flutamide A review of its pharmacodynamic and pharmacokinetic properties, and therapeutic use in advanced prostatic cancer Drugs Aging 1: 104-115.

31. Pittenger MF, Mackay AM, Beck SC, Jaiswal RK, Douglas R, et al. (1999) Multilineage potential of adult human mesenchymal stem cells. Science 284 143-147.

32. Kocsis JD, Akiyama Y, Radtke C (2004) Neural precursors as a cell source to repair the demyelinated spinal cord. J Neurotrauma 21: 441-449.

33. Suzuki H, Taguchi T, Tanaka H, Kataoka H, Li Z, et al. (2004) Neurospheres induced from bone marrow stromal cells are multipotent for differentiation into neuron, astrocyte, and oligodendrocyte phenotypes. Biochem Biophys Res Commun 322: 918-922.

34. Eglitis MA, Mezey E (1997) Hematopoietic cells differentiate into both microglia and macroglia in the brains of adult mice. Proc Natl Acad Sci USA 94: 40804085 .

35. Kopen GC, Prockop DJ, Phinney DG (1999) Marrow stromal cells migrate throughout forebrain and cerebellum, and they differentiate into astrocytes after injection into neonatal mouse brains. Proc Natl Acad Sci USA 96: 1071110716.

36. Mezey E, Key S, Vogelsang G, Szalayova I, Lange GD, et al. (2003) Transplanted bone marrow generates new neurons in human brains. Proc Nat Acad Sci USA 100: 1364-1369.

37. Sasaki M, Honmou O, Akiyam Y, Uede T, Hashi K, et al. (2001) Transplantation of an acutely isolated bone marrow fraction repairs demyelinated adult rat spinal cord axons. Glia 35: 26-34.

38. Akiyama Y, Radtke C, Honmou O, Kocsis JD (2002) Remyelination of the spinal cord following intravenous delivery of bone marrow cells. Glia 39: 229-236. 
Citation: Tiftikcioglu BI, Rice CM, Karabudak R, Scolding NJ (2012) Neurosteroid Hormones Modulate the Differentiation of Adult Human Multipotent Mesenchymal Stromal Cells. J Stem Cell Res Ther S4:003. doi:10.4172/2157-7633.S4-003

39. Akiyama Y, Radtke C, Kocsis JD (2002) Remyelination of the rat spinal cord by transplantation of identified bone marrow stromal cells. J Neurosci 22: 66236630

40. Rice CM, Mallam EA, Whone AL, Walsh P, Brooks DJ, et al. (2010) Safety and Feasibility of Autologous Bone Marrow Cellular Therapy in RelapsingProgressive Multiple Sclerosis. Clin Pharmacol Ther 87: 679-685.

41. Savitz SI, Misra V, Kasam M, Juneja H, Cox CS, et al. (2011) Intravenous autologous bone marrow mononuclear cells for ischemic stroke. Ann Neurol 70: $59-69$

42. Greer JM, McCombe PA (2011) Role of gender in multiple sclerosis: clinical effects and potential molecular mechanisms. J Neuroimmunol 234: 7-18.

43. Grinsted L, Heltberg A, Hagen C, Djursing H (1989) Serum sex hormone and gonadotropin concentrations in premenopausal women with multiple sclerosis. J Intern Med 226: 241-244

44. Foster SC, Daniels C, Bourdette DN, Bebo BF Jr (2003) Dysregulation of the hypothalamic-pituitary-gonadal axis in experimental autoimmune encephalomyelitis and multiple sclerosis. J Neuroimmunol 140: 78-87.

45. Abramsky O, Lubetzki-korn I, Evron S, Brenner T (1984) Suppressive effect of pregnancy on MS and EAE. Prog Clin Biol Res 146: 399-406.

46. Confavreux C, Hutchinson M, Hours MM, Cortinovis-Tourniaire $P$, Moreau T (1998) Rate of pregnancy-related relapse in multiple sclerosis. Pregnancy in Multiple Sclerosis Group. N Engl J Med 339: 285-291.

47. Confavreux C, Hutchinson M, Hours MM, Cortinovis-Tourniaire $P$, Moreau $T$ (1998) Rate of pregnancy-related relapse in multiple sclerosis. Pregnancy in Multiple Sclerosis Group. N Engl J Med 339: 285-291.

48. Sicotte NL, Liva SM, Klutch R, Pfeiffer P, Bouvier S, et al. (2002) Treatment of multiple sclerosis with the pregnancy hormone estriol. Ann Neurol 52: 421-428.

49. Keith $A B$ (1978) Effect of pregnancy on experimental allergic encephalomyelitis in guinea pigs and rats. J Neurol Sci 38: 317-326.

50. Langer-Gould A, Garren H, Slansky A, Ruiz PJ, Steinman L (2002) Late pregnancy suppresses relapses in experimental autoimmune encephalomyelitis: evidence for a suppressive pregnancy-related serum factor. J Immunol 169 : 1084-1091.

51. Bebo BF Jr, Zelinka-Vincent E, Adamus G, Amundson D, Vandenbark AA, et al (1998) Gonadal hormones influence the immune response to PLP 139-151 and the clinical course of relapsing experimental autoimmune encephalomyelitis. $J$ Neuroimmunol 84: 122-130.

52. Trooster WJ, Teelken AW, Gerrits PO, Lijnema TH, Loof JG, et al. (1996) The effect of gonadectomy on the clinical course of chronic experimental allergic encephalomyelitis. Clin Neurol Neurosurg 98: 222-226.

53. Palaszynski KM, Liu H, Loo KK, Voskuhl RR (2004) Estriol treatment ameliorates disease in males with experimental autoimmune encephalomyelitis: implications for multiple sclerosis. J Neuroimmunol 149: 84-89.

54. Palaszynski KM, Loo KK, Ashouri JF, Liu HB, Voskuhl RR (2004) Androgens are protective in experimental autoimmune encephalomyelitis: implications for multiple sclerosis. J Neuroimmunol 146: 144-152.

55. Offner H, Adlard K, Zamora A, Vandenbark AA (2000) Estrogen potentiates treatment with $\mathrm{T}$-cell receptor protein of female mice with experimental encephalomyelitis. J Clin Invest 105: 1465-1472.

56. Dalal M, Kim S, Voskuhl RR (1997) Testosterone therapy ameliorates experimental autoimmune encephalomyelitis and induces a $T$ helper 2 bias in the autoantigen-specific T lymphocyte response. J Immunol 159: 3-6.

57. Zhang Z, Cerghet M, Mullins C, Williamson M, Bessert D, et al. (2004) Comparison of in vivo and in vitro subcellular localization of estrogen receptors alpha and beta in oligodendrocytes. J Neurochem 89: 674-684.
58. Jung-Testas I, Renoir M, Bugnard H, Greene GL, Baulieu EE (1992) Demonstration of steroid hormone receptors and steroid action in primary cultures of rat glial cells. J Steroid Biochem Mol Biol 41: 621-631.

59. Takao T, Flint N, Lee L, Ying X, Merrill J, et al. (2004) 17beta-estradiol protects oligodendrocytes from cytotoxicity induced cell death. J Neurochem 89: 660673

60. Curry JJ III, Heim LM (1966) Brain myelination after neonatal administration of oestradiol. Nature 209: 915-916.

61. Koenig HL, Schumacher M, Ferzaz B, Thi AN, Ressouches A, et al. (1995) Progesterone synthesis and myelin formation by Schwann cells. Science 268 1500-1503.

62. Koenig HL, Gong WH, Pelissier P (2000) Role of progesterone in periphera nerve repair. Rev Reprod 5: 189-199.

63. Ghoumari AM, Ibanez C, El-Etr M, Leclerc P, Eychenne B, et al. (2003) Progesterone and its metabolites increase myelin basic protein expression in organotypic slice cultures of rat cerebellum. J Neurochem 86: 848-859.

64. Ibanez C, Shields SA, El-Etr M, Baulieu EE, Schumacher M, et al. (2004) Systemic progesterone administration results in a partial reversal of the ageassociated decline in CNS remyelination following toxin-induced demyelination in male rats. Neuropathol Appl Neurobiol 30: 80-89.

65. Gago N, Akwa Y, Sananes N, Guennoun R, Baulieu EE, et al. (2001) Progesterone and the oligodendroglial lineage: stage-dependent biosynthesis and metabolism. Glia 36: 295-308.

66. Balthazart J, Ball GF (1998) New insights into the regulation and function of brain estrogen synthase (aromatase). Trends Neurosci 21: 243-249.

67. Pozzilli C, Tomassini V, Marinelli F, Paolillo A, Gasperini C, et al. (2003) 'Gender gap' in multiple sclerosis: magnetic resonance imaging evidence. Eur J Neurol 10: 95-97.

68. Voskuhl RR, Palaszynski K (2001) Sex hormones in experimental autoimmune encephalomyelitis: implications for multiple sclerosis. Neuroscientist 7: 258270 .

69. Caruso A, Di Giorgi Gerevini V, Castiglione M, Marinelli F, Tomassini V, et al (2004) Testosterone amplifies excitotoxic damage of cultured oligodendrocytes. J Neurochem 88: 1179-1185.

70. Ibanez C, Shields SA, El-Etr M, Leonelli E, Magnaghi V, et al. (2003) Steroids and the reversal of age-associated changes in myelination and remyelination. Prog Neurobiol 71: 49-56.

71. Baulieu E, Schumacher M (2000) Progesterone as a neuroactive neurosteroid, with special reference to the effect of progesterone on myelination. Steroids 65: 605-612.

This article was originally published in a special issue, Cell Therapy for neurological disorders handled by Editor(s). Dr. Pranela Rameshwar, UMDNJ-New Jersey Medical School, USA 